\title{
From MANy DifFERENT STONES: A House OF Justice
}

\section{The Honourable Claire L'HeureuX-DubÉ*}

The author argues that globalization has had a profound effect on both judging and lawyering, particularly in the area of international human rights. Because human rights issues arise in several jurisdictions concurrently, and because of advanced communications technology, judges and lawyers are increasingly able to incorporate material from across the globe into their decisions and arguments. Canadian judges and lawyers must grapple with issues concerning the implementation of international documents in Canadian law, and do so without much familiarity with international law. Several Supreme Court of Canada decisions make reference to international instruments as relevant considerations, but not necessarily binding authority. The persuasive character of international decisions depends on their contexts - some of which are and some of which are not appropriate to apply domestically. The author concludes with a call to all legal practitioners to participate fully in the increasing international legal dialogue.
L'auteur discute de la mondialisation dont l'effet a profondément marqué la profession d'avocat et de juge, tout spécialement dans le domaine des droits de la personne internationaux. Étant donné que les questions relatives aux droits de la personne apparaissent dans plusieurs juridictions simultanément, et compte tenu du niveau avancé de la technologie des communications, les juges et les avocats peuvent de plus en plus incorporer du matériel venant de partout au monde dans leurs décisions et plaidoiries. Les juges et avocats canadiens doivent lutter avec les questions relatives à l'implantation de documents internationaux dans le droit canadien et le faire sans être familier avec le droit international. Plusieurs décisions de la Cour suprême du Canada font référence aux instruments internationaux en tant que considérations pertinentes sans pour autant avoir une autorité obligatoire. Le caractère persuasif des décisions internationales dépend de leur contexte - certains pouvant convenir au pays, d'autres pas. L'auteur se termine par un appel à tous les hommes et femmes de loi de participer pleinement au dialogue juridique qui prend de plus en plus une dimension internationale.

\section{TABLE OF CONTENTS}

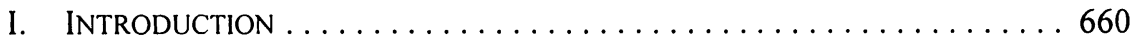

II. EMERGENCE OF GLOBALIZATION AND EVOLUTION

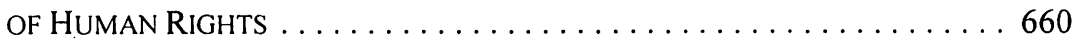

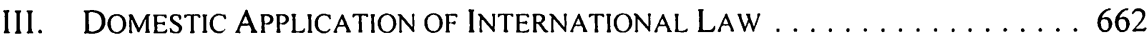

A. THE REach of International LaW $\ldots \ldots \ldots \ldots \ldots \ldots \ldots 62$

B. CANADIAN JURISTS' UNFAMILIARITY WITH INTERNATIONAL HUMAN RIGHTS LAW . . . . . . . . . . . 662

C. NEED FOR EDUCATIONAL INFORMATION ON INTERNATIONAL HUMAN RIGHTS LAW . . . . . . . . . . . 663

D. IMPACT OF INTERNATIONAL INSTRUMENTS

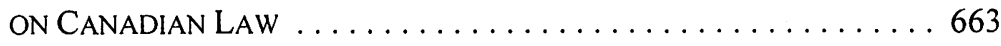

IV. SUPREME COURT OF CANADA, INTERNATIONAL HUMAN RightS COVENANTS, AND INTERNATIONAL LAW ............ 664

V. Persuasive Authority of International LAW . . . . . . . . . 667

VI. CONCLUSION .............................. 669

Former Justice of the Supreme Court of Canada. A version of this article was presented to a meeting of the International Association of Women Judges (10 November 2001, Montreal, Quebec). 


\section{INTRODUCTION}

Globalization has affected technological, economic, and cultural spheres, and with the unfolding of the new millennium, it is evident that globalization has affected judging and lawyering as well. After World War II, the United Nations adopted the Universal Declaration of Human Rights, ' and a human rights culture had begun to spread across the globe. These two phenomena sparked an increase in legal influence that stretched across borders. Globalization in judging means that courts now look all over the world for sources of authority; as a result, the process of international influence has changed from reception to dialogue. Some judges used to be "givers" of law, while others were passive recipients who may have applied or modified cases for their own jurisdictions. Today, persuasive authority flows throughout the international judging community and reception has turned into multilateral dialogue. International law in general, and international human rights law in particular, are increasingly relevant to the Canadian legal community. Canadian judges and lawyers must realize that the legal community has now become a global one, and that others look to Canadian courts for analysis in human rights law, just as Canadians have relied upon others. As Chief Justice Abrahamson of the Supreme Court of Wisconsin notes:

[w] hether other countries' legal developments will move our courts into a new stage of thinking, there is no question that changes in the world as a whole have catapulted our courts onto a new stage in a legal production as wide as the globe itself. Under such circumstances, stage fright is understandable. But like it or not, the world is now our courtroom. ${ }^{2}$

\section{EMERGENCE of Globalization and Evolution of HuMAN Rights}

The legal world is becoming a global one, and increasing dialogue among the world's legal practitioners is taking place for a number of reasons. A leading factor and, in my view, the starting point of globalization in the judicial world and the parallel phenomenon of the international human rights culture, is the adoption in 1948 of the Universal Declaration. Following that, the United Nations introduced the International Covenant on Civil and Political Rights, ${ }^{3}$ the Optional Protocol to the Covenant on Civil and Political Rights, ${ }^{4}$ and the International Covenant on Economic, Social and Cultural Rights. ${ }^{5}$ These instruments provide international norms and standards to which the world community is expected to adhere, and set a standard of achievement toward which all nations strive. The principles they contain have been reflected in new constitutions, other human rights treaties, and their progeny.

Links abound between international rights documents and national or regional human rights guarantees and provisions. The drafters of the Canadian Charter of Rights and

GA Res. 217(III), UN GAOR, 3d Sess., Supp. No. 13, UN Doc. A/180 (1948) 71 [Universal Declaration].

2 See Shirley S. Abrahamson \& Michael J. Fischer, "All the World's a Courtroom: Judging in the New Millennium" (1997) 26 Hofstra L. Rev. 273 at 292.

19 December 1966, 999 U.N.T.S. 171, Can. T.S. 1976 No. 47

19 December 1966, 999 U.N.T.S. 302, Can. T.S. 1976 No. 47

16 December 1966, 1007 U.N.T.S. 389, Can. T.S. 1976 No. 46 
Freedoms,${ }^{6}$ for example, drew extensively on international human rights treaties, ${ }^{7}$ and those who put together the human rights protections in South Africa and Israel used the Canadian Constitution and human rights treaties among their sources. ${ }^{8}$ These links are reflected in the similar language, organization, and principles of many human rights guarantees. Given the similarities of constitutional drafting and sources, one would not be surprised by the new dialogue among judges and lawyers drawing on the expertise and experience of interpreters of similar documents. Moreover, because the legal protection of human rights is a novel phenomenon in many countries, sometimes, little or no previous domestic jurisprudence exists to give meaning to the rights, making judgments from elsewhere particularly useful and necessary. Deciding on applicable legal principles and solutions increasingly involves a consideration of the approaches that have been adopted for similar legal problems elsewhere.

The fact that courts throughout the world have been facing the same issues has greatly contributed to the globalization of our legal world. Terrorism, extradition, hate speech, gay and lesbian rights, environmental protection, intellectual property, and trade, to name just a few, are issues that judges in different jurisdictions must deal with at roughly the same time. As social debates and discussions around the world become more and more similar, so do the equivalent legal debates.

The progress of communication technology is another factor that has influenced and advanced the dialogue. International documents, legislation, and jurisprudence from around the world are literally at our fingertips. ${ }^{9}$ Computers and electronic databases give access to decisions in a broad range of jurisdictions, and anyone with a connection to the World Wide Web can obtain, free of charge, recent decisions of Canada's Supreme Court by simply going to its website. ${ }^{10}$ Decisions of other courts around the world are also diffused electronically, and numerous internet sites consolidate access to banks of case law, statutes, and other materials from various jurisdictions. These technological developments make it much easier, quicker, and less costly to consult comparative constitutional sources, refer to them in argument, or quote them in judgments.

The growing personal contact between law professionals from different countries has also contributed to this international dialogue. Judges and lawyers from various countries often discuss common problems at international conferences, by email, and over the telephone. Close interactions among jurists around the world are now becoming commonplace. The legal community is a large family and we reach out so much more easily when we know each

" Part I of the Constitution Act, 1982, being Schedule B to the Canada Act 1982, (U.K.), 1982, c. 11 [Charter].

$7 \quad$ See Anne F. Bayefsky, "International Human Rights Law in Canadian Courts" in Benedetto Conforti \& Francesco Francioni, eds., Enforcing International Human Rights in Domestic Courts (The Hague and Boston: Nijhoff, 1997) 295 at 310; and John Claydon, "International Human Rights Law and the Interpretation of the Canadian Charter of Rights and Freedoms" (1982) 4 Sup. Ct. L. Rev. 287 at 287.

$8 \quad$ See e.g. Adam M. Dodek, "The Charter ... In the Holy Land?" (1996) 8:1 Const. Forum Const. 5; Lorraine Weinrib, "The Canadian Charter as a Model for Israel's Basic Laws" (1993) 4:3 Const. Forum Const. 85.

" Abrahamson \& Fischer, supra note 2 at 291.

11) The Supreme Court of Canada, online: Supreme Court of Canada and LexUM <www.lexum. umontreal.ca/csc-scc>. 
other and can identify the authors of decisions. In this way, personal interaction breaks down any perceived communication barriers.

\section{DOMESTIC APPLICATION Of INTERNATIONAL LAW}

Since we are part of a global legal culture and can no longer ignore international instruments, the question then becomes, how should judges and lawyers deal with the domestic implementation of international documents in Canadian law beyond mere participation in international dialogue?

\section{A. The Reach of INTERNATIONAL LAW}

In the past, international law predominantly regulated matters of diplomatic relevance such as war, treatment of aliens, immunities, and maritime affairs. Today, international law pervades areas traditionally reserved for the domestic jurisdiction of states, such as human rights, crime, trade, natural resource use, environmental conservation and management, and cultural heritage conservation. That view was expressed recently by Professor Francioni, ${ }^{11}$ who added:

[a]djudication in these areas sometimes requires a difficult blending of national and international norms and the application of techniques to solve possible conflicts between the two legal orders, as well as the dilemma of how to reconcile separation of powers between the executive and the judiciary with the rule of law and the independence of judges. $^{12}$

\section{B. CANADIAN JURISTS' UNFAMILIARITY WITH INTERNATIONAL HUMAN RIGHTS LAW}

Dean Leuprecht stated recently, when appearing before the Senate Committee on Human Rights, that Canada is party to about 4,000 international treaties and about 40 treaties dealing with human rights, and that contrary to the United States, Canada has a very good record of ratifying international human rights treaties. He also mentioned that Canada enjoys enormous prestige internationally as it not only ratifies, but is very often a promoter and initiator of international treaties. $^{13}$

He added, however, that " $[t]$ here is in the country a widespread unfamiliarity of both bench and bar with international law and international human rights law." ${ }^{14} \mathrm{He}$ illustrated this point by noting that "[a]lthough some 500 Canadian court decisions refer to international human rights treaties, ... considering the number and scope of human rights instruments ratified by Canada and the volume of traditional activity of this big country, the silence of Canadian courts is more eloquent than their pronouncements." 15

Francesco Francioni, "International Law as a Common Language for National Courts" (2001) 36 Tex. Int'I L.J. 587.

Ibid. at 588 .

Standing Senate Committee on Human Rights, (1 October 2001) 1600-17 and 1600-28 (Peter Leuprecht).

Ibid. at $1600-19$.

Ibid. 


\section{NEED FOR EDUCATIONAL INFORMATION ON INTERNATIONAL HUMAN RIGHTS LAW}

That Canada plays a pioneering role on the international scene when it comes to international human rights instruments is illustrated by the sheer number of key UN human rights treaties and declarations signed by Canada, including the International Covenant on Civil and Political Rights, the International Covenant on Economic, Social and Cultural Rights, the International Convention on the Elimination of All Forms of Racial Discrimination, ${ }^{16}$ the Convention Against Torture,${ }^{17}$ and the Convention on the Rights of the Child. ${ }^{18}$ Canada also played a strong leadership role in the creation of the International Criminal Court. ${ }^{19}$ Accordingly, the Canadian legal community must be aware of our international commitments and judges and lawyers must be well-informed of the existence and nature of these international instruments. Dean Leuprecht noted that "certain court decisions of Canadian courts are proof of an alarming ignorance of international law and international human rights law." ${ }^{20}$ As a result, education for all jurists on international law and international human rights conventions now, more than ever, is a necessity for the whole legal community. Lord Mance expressed this same opinion when he stated that domestic judges "have increasingly to understand and take account of principles with international and foreign origins. It is not only 'fundamentals in our society and culture' to which they must be sensitive. It is fundamentals which are generally accepted internationally to which they must increasingly give effect."21

\section{IMPACT OF INTERNATIONAL INSTRUMENTS ON CANADIAN LAW}

Once familiar with international instruments, the issue remains: what weight should they be given in domestic law? When Canada signs and ratifies an international treaty, at a minimum judges and lawyers should be aware of its existence, and should assess its relevance to the specific issues before them. The fact that Canada is party to international human rights instruments certainly signals a commitment to abide by the terms of such documents and the values they represent. In short, their existence cannot be ignored by the legal community any more than we can ignore jus cogens in international law. Professor Kindred has explained that principles of international law that have the status of jus cogens can be found in treaties and customs, and that they are obligations owed by a state to the international community as a whole. ${ }^{22}$ We need to be aware of this "open set of peremptory norms of international law" 23 and to take into account their relevance to particular issues.

The next issue relates to the effect of the incorporation of international instruments in Canadian law. The vast majority of international instruments must be implemented by

7 March 1966, 1543 U.N.T.S. 304.

10 December 1984, 1547 U.N.T.S. 466.

20 November 1989,1577 U.N.T.S. 3.

Standing Senate Committee on Human Rights, (1 October 2001) 1600-2 (Marilou McPhedran).

Supra note 13 at 1600-19.

See The Right Honourable Lord Justice Mance, "Foreign and Comparative Law in the Courts" (2001)

36 Tex. Int'l L.J. 415 at 426.

22 Hugh M. Kindred et al., International Law, Chiefly as Interpreted and Applied in Canada, 6th ed. (Toronto: Emond Montgomery, 2000). 
legislation to have effect in Canadian law. Furthermore, as a result of the separation of powers between ss. 91 and 92 of the Constitution Act, $1867,{ }^{24}$ Parliament has no special jurisdiction to implement international instruments that pertain to matters within provincial legislative jurisdiction. Jurisdiction to adopt laws for the purpose of implementing such instruments is determined by the ordinary constitutional rules governing the division of legislative powers. ${ }^{25}$

An international document that has been implemented by either Parliament or a provincial legislature becomes a source of rights and obligations, and will be applied by courts as part of the laws of Canada. More difficult is the question of the account that should be given to a treaty that has been signed and duly ratified by Canada, but has not been implemented by domestic statutes. Another writer points out that "[a]lthough the courts have said often enough that a treaty must be implemented by legislation in order to change existing Canadian law, they have not wholly excluded the influence of unimplemented conventions."26

Two incorporation methods of unimplemented treaties are possible. One method is for the text of a treaty to be incorporated into national law, either entirely or in parts. The treaty is thus the source of rights and obligations as it becomes Canadian law. A second method is for the substance of the treaty to be incorporated into domestic law. The treaty itself does not become part of the domestic law and accordingly does not confer rights nor impose obligations. However, the values reflected in the international convention may help inform the interpretation of the domestic statute. A good example of this is Quebec's adoption of $A n$ Act respecting the civil aspects of international and interprovincial child abduction, ${ }^{27}$ which incorporates the principles set forth in the Convention on the Civil Aspects of International Child Abduction. ${ }^{28}$ Quebec's Court of Appeal accordingly analyzed and interpreted the Quebec statute by taking into account the purpose and philosophy of the Convention. ${ }^{29}$

\section{SUPREME COURT OF CANADA, INTERNATIONAL HUMAN RightS COVENANTS, AND INTERNATIONAL LAW}

Though the Supreme Court of Canada has not answered all of the questions concerning untransformed treaty norms, it has ventured into the domain of international law on many occasions, including very recently. Regarding earlier cases, Professor Toope wrote:

the Supreme Court has adopted two interpretive presumptions that have a long history in the common law: first, that unless there are unmistakable signals pointing to the non-conformity of Canadian law with an international obligation, domestic law, including statutes and the Charter, should be interpreted to uphold Canada's treaty commitments (See R. v. Keegstra, [1990] 3 S.C.R. 697; National Corn Growers Assn. v. Canada (Import Tribunal), [1990] 2 S.C.R. 1324 at 1371-72 (per Gonthier J.); and Pushpanathan v. Canada (Minister of Citizenship and Immigration), [1998] I S.C.R. 982 at 1019-22 (per Bastarache J.)). Second, that in interpreting ambiguous domestic legislation, recourse should be had to underlying international treaty 
commitments (See Capital Cities Comm. Inc. v. C.R.T.C, [1978] 2 S.C.R. 141; and the opinion of lacobucci J. in Baker v. Canada (Minister of Citizenship and Immigration), [1999] 2 S.C.R. 817 (dissenting in part)). ${ }^{30}$

Dean Leuprecht commented that "the Supreme Court of Canada, when it moves into international law, does not seem to be on very safe ground." ${ }^{\text {11 }}$ This may not be unique to Canada given that Professor Charlesworth stated:

[o]verall, in many contexts, international law is seen as a problematic and subversive influence on national legal orders, introducing chaos and uncertainty. Indeed, Stephen Toopes argues that the story of international law in Canada implicates the nation's identity and social cohesion - who "we" are and who "other" are. ${ }^{32}$

In answering the international law question in Reference re Secession of Quebec, ${ }^{33}$ the Supreme Court referred to a number of international documents and, as Professor Toope noted, "the Court expressly treated international law (including customary law, treaties ratified by Canada, and declarations of intergovernmental organizations and assemblies) merely as a "consideration." 34

The R.v. Ewanchuk $k^{35}$ decision provided an opportunity to refer to the Convention on the Elimination of All Forms of Discrimination against Women, ${ }^{36}$ and to the Declaration on the Elimination of Violence against Women. ${ }^{37}$ In a concurring opinion, I stated that "[a]lthough not a treaty binding states, [the Declaration] sets out a common international standard that U.N. members states are invited to follow." ${ }^{38}$ I added:

[o]ur Charter is the primary vehicle through which international human rights achieve a domestic effect (see Slaight Communications Inc. v. Davidson, [1989] I S.C.R. 1038; R. v. Keegstra, [1990] 3 S.C.R. 697). In particular, s. 15 (the equality provision) and s. 7 (which guarantees the right to life, security and liberty of the person) embody the notion of respect of human dignity and integrity. ${ }^{39}$

In Baker v. Canada (Minister of Citizenship and Immigration), ${ }^{40}$ in which the Supreme Court dealt with immigration law, the majority referred to the Convention on the Rights of the Child and concluded that

[i]nternational treaties and conventions are not part of Canadian law unless they have been implemented by statute: Francis v. The Queen, [1956] S.C.R. 618, at p. 621; Capital Cities Communications Inc. v. Canadian Radio-Television Commission, [1978] 2 S.C.R. 141, at pp. 172-73. [...] Nevertheless, the values reflected in

Stephen J. Toope, "The Uses of Metaphor: International Law and the Supreme Court of Canada," (March-June 2001) Can. Bar. Rev. 534 at 538 [Toope, "Uses of Metaphor"].

Leuprecht, supra note 13 at $1600-19$.

Hilary Charlesworth, "Keynote Paper" (Presented to the International Association of Women Judges, Montreal, Quebec, November 2001) [unpublished].

[1998] 2 S.C.R. 217.

Stephen J. Toope, "Case Comment" (1999) 93 A.J.I.L. 519 at 523 [Toope, "Case Comment"]. [1999] 1 S.C.R. 330.

18 December 1979, 1257 U.N.T.S. 496, Can. T.S. 1982 No. 31.

G.A. Res. 48/104, UN ESC, 1993, U.N. Doc. E/RES/1993/10 E/1993/INF/6.

Ibid. at para. 72 .

Ibid. at para. 73.

[1999] 2 S.C.R. 817. 
international human rights law may help inform the contextual approach to statutory interpretation and judicial review... The important role of international human rights law as an aid in interpreting domestic law has also been emphasized in other common law countries: see, for example, Tavita v. Minister of Immigration, [1994] 2 N.Z.L.R. 257 (C.A.), at p. 266; Vishaka v. Rajasthan, [1997] 3 L.R.C. 361 (S.C. India), at p. 367. It is also a critical influence on the interpretation of the scope of the rights included in the Charter: Slaight Communications, supra; R. v. Keegstra, [1990] 3 S.C.R. $6977^{41}$

In United States of America v. Burns, ${ }^{42}$ the Supreme Court took note of the growing body of international documents and of the factual developments in Canada and relevant foreign jurisdictions, and alluded to Canada's ratification of various international instruments in relation to the death penalty. In particular, the Court stated:

[t]he United Nations Commission on Human Rights Resolutions 1999/61 (adopted April 28, 1999) and 2000/65 (adopted April 27, 2000) call for the abolition of the death penalty, and in terms of extradition state that the Commission

[r] equests States that have received a request for extradition on a capital charge to reserve explicitly the right to refuse extradition in the absence of effective assurances from relevant authorities of the requesting State that capital punishment will not be carried out;

Canada supported these initiatives. When they are combined with other examples of Canada's international advocacy of the abolition of the death penalty itself, as described below, it is difficult to avoid the conclusion that in the Canadian view of fundamental justice, capital punishment is unjust and it should be stopped. ${ }^{43}$

In a case dealing with the banning of pesticides, the Supreme Court had this to say in 114957 Canada Ltée (Spraytech, Société d'arrosage) v. Hudson (Town):

[t]he interpretation of By-law 270 contained in these reasons respects international law's "precautionary principle," which is defined as follows at para. 7 of the Bergen Ministerial Declaration on Sustainable Development (1990):

In order to achieve sustainable development, policies must be based on the precautionary principle....

Scholars have documented the precautionary principle's inclusion "in virtually every recently adopted treaty and policy document related to the protection and preservation of the environment" (D. Freestone and E. Hey, "Origins and Development of the Precautionary Principle," in D. Freestone and E. Hey, eds., The Precautionary Principle and International Law (1996), at p. 41. As a result, there may be "currently sufficient state practice to allow a good argument that the precautionary principle is a principle of customary international law" (J. Cameron and J. Abouchar, "The Status of the Precautionary Principle in International Law," in ibid., at p. 52). See also O. McIntyre and T. Mosedale, "The Precautionary Principle as a Norm of Customary International Law"(1997), 9 J. Env. L. 221, at p. 241 ("the precautionary principle has indeed crystallised into a norm of customary international law"). The Supreme Court of India considers the precautionary principle to be "part of the Customary International Law" (A.P. Pollution Control Board v. Nayudu, 1999 S.O.L. Case No. 53, at para. 27). See also Vellore Citizens Welfare Forum v. Union of India, [1996] Supp. 5 S.C.R. 241. In the context of the precautionary principle's tenets, the Town's concerns about pesticides fit well under their rubric of preventive action. ${ }^{44}$ 
While some academics have indicated that the Supreme Court could have "clarif[ied] the role played by public international law within the Canadian legal system," recognized the "new, more open attitude of the Supreme Court of Canada to the influence, if not authority, of international law."

\section{Persuasive Authority of International LaW}

This brings me to the persuasive authority of the international application and interpretation of similar human rights instruments. As Lord Mance noted, it is a wellestablished approach for domestic courts to consider the interpretation of an international treaty by other domestic courts. ${ }^{47}$ He pointed out that in this era of globalization, domestic judges are increasingly called upon to look at domestic issues from a wider perspective, and are required to stand outside their own legal system to consider if other views may be appropriate. ${ }^{48}$ In this sense, one can only agree with Professor Davis when she wrote that "[g]lobalization has now so pervaded our national culture and identities that a court that consistently ignores international precedents and experiences when considering human rights issues, even if merely for their persuasive or moral weight, risks irrelevancy." 49

In stressing the importance and the growing relevance of drawing upon legal developments in other countries, Chief Justice Abrahamson stateds that failing to survey the international landscape "would be like reading only majority opinions and never turning to concurrences or dissents. ${ }^{50}$

In this regard, the Supreme Court of Canada recently held in Burns that when interpreting a convention in the field of human rights law, judges cannot limit themselves to what occurs in Canada. Rather, they must look at the overall principles promoted by other democratic regimes comparable to Canada. In the same way, references by international tribunals to the authority of the Supreme Court of Canada are becoming more frequent. ${ }^{51}$

Rather than comparative law being a one-way transmission of existing law from some jurisdictions to others, the development of human rights jurisprudence, in particular, is increasingly becoming a dialogue. Take, as just one example among many, the Namibian case of Mwellie v. Ministry of Works. ${ }^{52}$ In that case, the High Court had to determine an appropriate interpretation of the guarantee of equality in the country's new constitution. In doing so, the Court looked to decisions from high courts in India, the United States, Canada, England, Malaysia, and South Africa, as well as to decisions of the European Court of Human Rights. Another example is the South African case of S. v. Makwanyane, ${ }^{53}$ where

Martha F. Davis, "International Human Rights and United States Law: Predictions of a Courtwatcher," (2000) 64 Alta. L. Rev. 417 at 421.

s1 William A. Schabas, "Twenty-Five Years of Public International Law at the Supreme Court of Canada" (2000) 79 Can. Bar Rev. 174. 
members of the Constitutional Court, in determining the constitutionality of the death penalty, examined in considerable detail decisions from India, Zimbabwe, Jamaica, Germany, Canada, the United States, the European Court of Human Rights, Hungary, the United Nations Committee on Human Rights, Botswana, Hong Kong, and Tanzania. Numerous other examples of dialogue are found in court decisions from Zimbabwe, Canada, Australia, and New Zealand. Importantly, the European Court of Human Rights has also begun to have a significant impact on the shape of human rights law both within and outside Europe. ${ }^{54}$

Despite the useful aspects of turning to solutions abroad, however, we must ensure that foreign reasoning is not imported without sufficient consideration of the context in which it is being applied. Solutions developed in one jurisdiction may be inappropriate elsewhere. Political and social realities, values, and traditions differ across borders, regions, and levels of development, thus requiring different solutions in different places.

This does not mean that it is not useful to look to decisions from jurisdictions where the context is different - only that simply importing foreign solutions is not always appropriate. Considering and articulating the differences that mandate the adoption of a different solution is, in my view, a particularly useful exercise. Cross-pollination helps not only when we accept the solutions and reasoning of others, but also when we depart from them. Even then, understanding and articulating the reasons for adopting a different solution for a particular country helps make a better decision. As Justice Breyer noted in his dissenting judgment in Printz v. United States, after referring to the constitutions of several other countries, "[o]f course, we are interpreting our own Constitution, not those of other nations, and there may be relevant political and structural differences between their systems and our own.... But their experience may nonetheless cast an empirical light on the consequences of different solutions to a common legal problem."

Professor Glendon has written pertinently about the rewards of comparative analysis, and she noted that

[w]e can only benefit from a heightened awareness of the ways in which other nations have approached problems with which our own legal system is currently struggling. ... And even when it does not immediately move us into a new stage of thinking, it nearly always afford us a deeper understanding of, and a more balanced perspective on, our own law. ${ }^{56}$

All of this being said, when interpreting the Canadian Charter, reference to international law will certainly be a fruitful source of inspiration and ideas, given the similarity of language contained in our Charter to that found in basic international human rights texts, and considering also that the Charter represents a fusion of classic liberties and human rights that may be found in many other systems. ${ }^{57}$ This view was expressed by Chief Justice Dickson (as he then was) in his dissenting opinion in the Reference Re Public Service Employee Relations Act (Alberta): 
The Charter conforms to the spirit of this contemporary international human rights movement, and it incorporates many of the policies and prescriptions of the various international documents pertaining to human rights. The various sources of international human rights law ... must, in my opinion, be relevant and persuasive sources for interpretation of the Charter's provisions. ${ }^{5 *}$

\section{CONCLuSION}

Due to the increased reliance on international conventions, documents, jurisprudence, and treaties, the factors that shape our law have burgeoned in recent years, while the number and the types of sources to which judges and lawyers must turn have diversified and expanded exponentially. It is my belief that those serving as judges and lawyers in the 21 st Century must engage in constant vigilance to keep abreast of the changing face of law around the globe - down to the most incremental jurisprudential shiftings of our sister countries.

I hold a firm belief that we can overcome our deficits in this area by developing new approaches to how we learn the facts and law of a case. Attending legal education seminars and exchanging ideas with one another will no doubt help to shed light on the relevance of international law in Canadian law. But whatever we do, we must each participate fully in this evolving globalized environment, first and foremost so that we can fulfill the one role that is unchanging: to render justice. And as the 21 st Century unfolds, it is my hope that all Canadian legal practitioners become active participants in weaving the tapestry of international law. In our legal labour, let us all make full use of every legal tool so that thereon, from many different stones will rise a house of justice. 